Agricore Volume 4 Nomor 1, Juli 2019

Jurnal Agribisnis dan Sosial Ekonomi Pertanian UNPAD

p-ISSN No. 2528-4576 / e-ISSN No. 2615-7411

\title{
STRATEGI PENGEMBANGAN BENIH BAWANG PUTIH DI KECAMATAN AGRAPURA KABUPATEN MAJALENGKA
}

\author{
Pandi Pardian 1 , Trisna Insan Noor ${ }^{2}$, Predi Nanda ${ }^{3}$ \\ 1, 2. Staf Pengajar Prodi Agribisnis Fakultas Pertanian Universitas Padjadjaran \\ 3. Peneliti dan alumni Pasca Sarjana Fakultas Pertanian Unpad \\ e-mail :pandip3@gmail.com
}

\begin{abstract}
Abstrak
Kabupaten Majalengka telah lama dikenal sebagai salah satu sentra bawang merah, selain bawang merah ternyata produksi bawang putih juga dilakukan di Kabupaten Majalengka. Salah satu kegiatan yang dilakukan pemerintah untuk mendukung produksi bawang putih di Kabupaten Majalengka adaalh dengan membuat program mengembangkan sistem produksi perbenihan bawang putih untuk mendukung produksi benih bawang secara kontinu dan berkualitas, sehingga hasil produksi bawang putih lebih baik dan berkembang. Program pengebangan benih bawang putih kerjasama dengan importir dari benih yang didatangkan oleh impotir tenyata memiliki beberapa permasalahan utama diantaranya tidak berumbi. Hal tersebut menarik peneliti untuk melakukan penelitian terkait strategi pengembangan benih bawang putih di Kabupaten Majalengka. Penelitian ini menggunakan metode survey sedangkan untuk mengetahui strategi pengembangan benih bawang putih dengnan alat analisis AHP (Analitycal Hierarchy Process). Sedangkan data yang dipergunakan dalam penelitian adalah data primer dan sekunder. Data primer didapatkan dari survey, sedangkan data sekunder diperoleh dari pencatatan/keterangan dari instansi terkait serta laporan hasil penelitian terdahulu. Hasil penelitian ini menunjukkan bahwa alternative strategi pengembangan benih bawang putih adalah melakukan kerjasaa dengn petani atau kelompok tani dengan penggunaan dan kesiapan teknologi budidaya serta jaminan pasar hasil produksi benih.
\end{abstract}

Kata Kunci : Bawang Putih, Benih, Analytical Hierarchy Proces, Majalengka.

\begin{abstract}
Majalengka Regency has been known as one of the centers of shallots. Besides shallots, in Majalengka Regency also it turns out garlic production. One of the activities carried out by the government to support garlic production in Majalengka Regency is creating a program to develop a production system for garlic seedlings to support continuous and quality production of onion seeds, so that garlic production is better and growing. The garlic seed development program in cooperation with importers has several main problems including non-tuber. This attracted researchers to conduct research related to the strategy of developing garlic seeds in Majalengka Regency. This study uses a survey method while to determine the strategy of developing garlic seeds with AHP (Analytical Hierarchy Proces). This study uses primary and secondary data. Primary data is obtained from surveys, while secondary data is obtained from recording/ information from relevant agencies and reports on previous research results. The study results indicate that the alternative strategy for developing garlic seeds is to collaborate with farmers or farmer groups with the use cultivation technology and market guaranteed for the seeds production.
\end{abstract}

Keywords: Garlic, Seeds, Analytical Hierarchy Proces, Majalengka. 


\section{Pendahuluan}

Bawang putih merupakan komoditas yang sangat penting bagi masyarakat Indonesia namun pada perkembangannya kebutuhan bawang putih dalam negeri belum bisa dipenuhi oleh sentra bawang putih nasional terutama Sembalum (Lombok-NTB), Jawa Tengah dan Jawa Barat sehingga kebijakan impor dilakukan. Data kementrian pertanian tahun 2016 konsumsi bawang putih nasional sebesar 465,1 ribu ton sedangkan produksi hanya mencapai 21,15 ribu ton. Adanya kebijakan pengurangan bertahap terhadap impor bawang putih dan kewajiban importir menanam 5\% dari kuota impornya, maka luas tanam bawang putih akan meningkat. Kebijakan pengurangan dilakukan untuk mengurangi ketergantungan kepada Negara lain dan mengebangkan lagi petani bawang putih nasional.

Program pengembangan bawang putih selain akan meningkatkan luas areal tanam di daerah yang memiliki potensi tanam bawang putih juga tentunya akan meningkatkan kebutuhan akan benih berkualitas. Salah satu daerah di Jawa Barat yang termasuk harus menjlankan program pengebangan benih bawang putih adalah Kabupaten Majalengka. Sebagai kabupaten yang lebih dikenal sebagai sentra bawang merah, petani di Kabupaten Majalengka dianggap bisa lebih cepat beradaptasi dalam mengebangkan benih bawang putih untuk memenuhi kebutuhan benih bawang putih petani dan pelaku usahatani bawang putih lainnya. Pengembangan benih bawang putih juga akan menghadapi kompetisi dengan komoditas sayuran lain yang sudah biasa dilakukan oleh petani, oleh karena itu dukungan pemerintah dengan menyediakan sarana produksi benih bawang putih diharapkan dapat menarik minat petani.

\section{Metode Penelitian}

Penelitian ini menggunakan metode survey. Metode survey adalah penelitian dengan cara sensus terhadap petani penangkar benih bawang putih yang di inisiasi oleh BPTP (Badan Pengkajian Teknologi Pertanian) Jawa Barat. Sedangkan data yang digunakana dalam penelitian ini adalah data primer dan data sekunder. Data primer didapatkan dari survey, dimana data dikumpulkan dengan mengamati dan melakukan wawancara terstruktur terhadap petani dan kelompok tani, importir bawang putih. Sementara data sekunder diperoleh dari pencatatan/keterangan dari instansi terkait, seperti Dinas Pertanian, BPTP, Badan Ketahanan Pangan, BPS (Badan Pusat Statistik), Kecamatan, Desa, serta laporan hasil penelitian terdahulu. Analisis pengolahan data menggunakan Analisis hirarki proses (AHP) yang merupakan salah satu metode yang dapat digunakan dalam pengambilan keputusan dengan memperhatikan faktor - faktor persepsi, preferensi, pengalaman dan intuisi yang digunakan dalam memecahkan persoalan kualitatif maupun kuantitatif. Analisi hirarki proses (AHP) memberikan pertimbangan secara intuitif selain pertimbangan ilmiah sehingga dapat memberikan pertimbangan dari cara berpikir yang sesuai dengan kondisi dan tidak berlawanan dengan hati nurani. Analisi hirarki proses (AHP) memberikan keluwuesan dalam menilai dengan menunjukkan pertimbangan dan nilai-nilai pribadi secara logis (Saaty, 1993:23).

\section{Hasil dan Pembahasan}


Agricore Volume 4 Nomor 1, Juli 2019

Jurnal Agribisnis dan Sosial Ekonomi Pertanian UNPAD p-ISSN No. 2528-4576 / e-ISSN No. 2615-7411

\section{Struktur model pengembangan benih} bawang putih di Kabupaten Majalengka.

Untuk mengetahui sistem produksi benih bawang putih di Kabupaten Majalengka, disusun matrik dengan menggunakan metode analisis hirarki proses (AHP). Kegiatan survey lapangan dan diskusi awal yang dilakukan dengan para pelaku pembenihan bawang putih. Stuktur model pengembangan benih bawang putih di Kabupaten Majalengka adalah sebagai berikut:

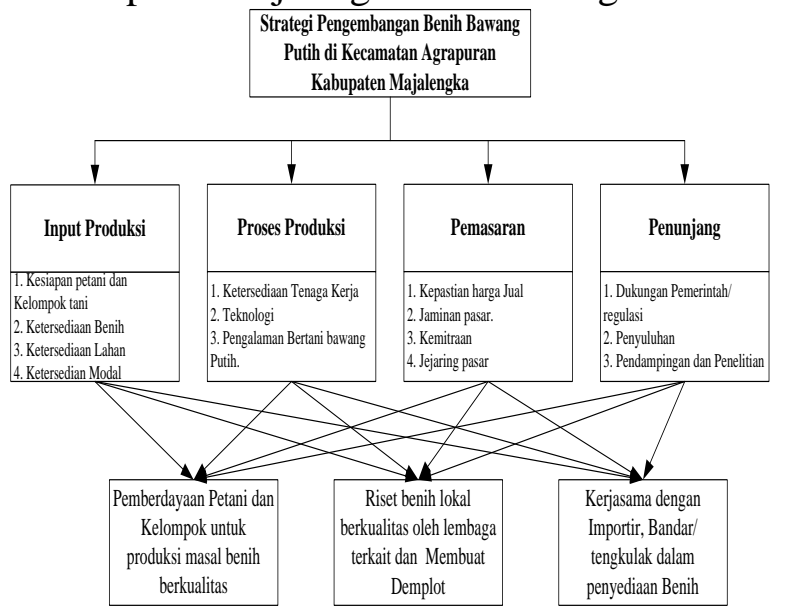

Gambar 1

struktur model produksi benih bawang putih

Sebagai salah satu sentra produksi bawang merah di Jawa Barat, ternyata Kabupaten Majalengka juga memproduksi bawang putih tepatnya di Kecamatan Argapura. Analisis AHP (Analisis Hirarki Proses) untuk melihat urutan prioritas penyebab berdasarkan struktur AHP yang dibuat yang terdiri dari kritera dan sub keriteria, untuk Kabupaten Majalengka khususnya daerah Kecamatan Agrapura sebagai lokasi kajian didapatkan hasil sebagai berikut:

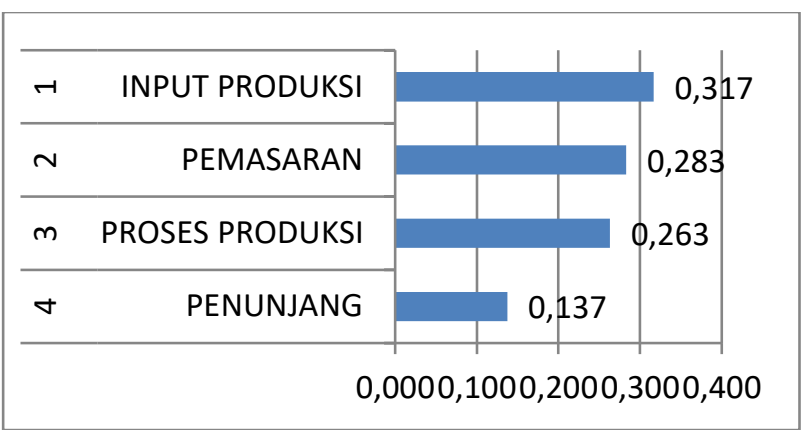

\section{Gambar 2}

Urutan Prioritas Kriteria model produksi Bawang Putih di Kecamatan Agrapura

Pada kategori kriteria, Input Produksi memiliki peranan terbesar (prioritas utama) yang menyebabkan program pengembangan benih bawang putih di Kecamatan Argapura Kabupaten Majalengka bisa dijalankan. Input produksi disini termasuk: Ketersedian Benih unggul, Modal kerja, Ketersediaan lahan dan kesiapan petani/kelompok tani mitra. Tanaman bawang putih dari benih yang diberikan oleh importir, tidak menghasilkan umbi sehingga petani secara nilai tidak menghasilkan apapun dan secara psikologis menurunkan minta untuk melakukan produksi bawang putih. Bagi importir hal tersebut tidak menjadi masalah karena merupakan biaya (cost) yang dikeluarkan untuk memenuhi kewajiban peraturan perundangundangan.

Penilaian sub kriteria pada produksi bawang putih Kecamatan Argapura

\section{Kriteria Input Produksi}

Pada kriteria Input Produksi dengan 4 sub kriteria, sub kriteria ketersediaan modal menjadi alasan dalam berproduksi benih bawang putih. Modal usahatani bawang putih untuk satu hektar di Kabupaten Majalengka sekita 35,8 - 40 juta. Dengan modal yang cukup besar dan dengan kemungkinan keberhasilan produksi bibit dibawah $50 \%$ menjadikan petani masih berpikir untuk memproduksi bibit kecuali sudah berhasil maka tidak menjadi masalah. Dari survey dan wawancara lapangan, bawang putih sudah lama 
di tanam oleh petani bawang putih di Majalengka namun dari penelusuran produksi benih bawang putih dilakukan dari benih awal secara turun temurun dan tidak ada yang khusus produksi benih bawang putih.

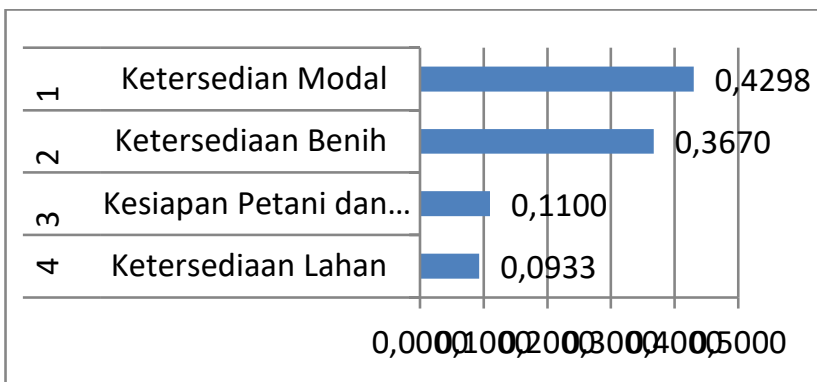

\section{Gambar 4}

Prioritas sub kriteria Input Produksi pengembangan benih bawang putih Kecamatan Argapura

\section{Kriteria Proses Produksi}

Pada kriteria Proses Produksi yang terdiri dari 3 sub kriteria, kriteria teknologi budidaya merupakan prioritas pertama yang menjadi kendala dalam pengembangan produksi benih bawang putih di Kecamatan Argapura Kabupaten Majalengka.

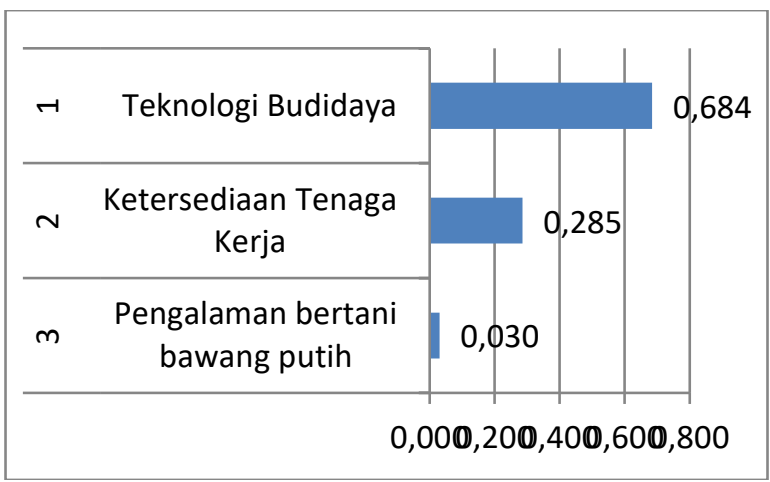

\section{Gambar 5}

Urutan Prioritas sub kriteria Proses Produksi pada proses produksi bawang putih di Kabupaten Majalengka

Petani Kecamatan Argapura merupakan petani yang biasa budidaya bawang merah.
Program pengembangan benih bawang putih yang diinisiasi oleh pemerintah melalui balai terkait saat penelitian di Kecamatan Argapura merupakan pengalaman pertama untuk budidaya bawang putih dan akan masuk pada musim tanam kedua. Pada musim pertama budidaya bawang putih petani Kecamatan Argapura mengalami kendala yaitu gagal panen disebabkan masih minimnya pengetahuan, teknik dan teknologi budidaya bawang putih.

\section{Kriteria Pemasaran}

Pada kriteri pemasaran, ada 4 sub kriteria dengan kriteria jaminan pasar yang menjadikan petani atau pelaku usahatani bawang untuk melakukan produksi bibit bawang putih.

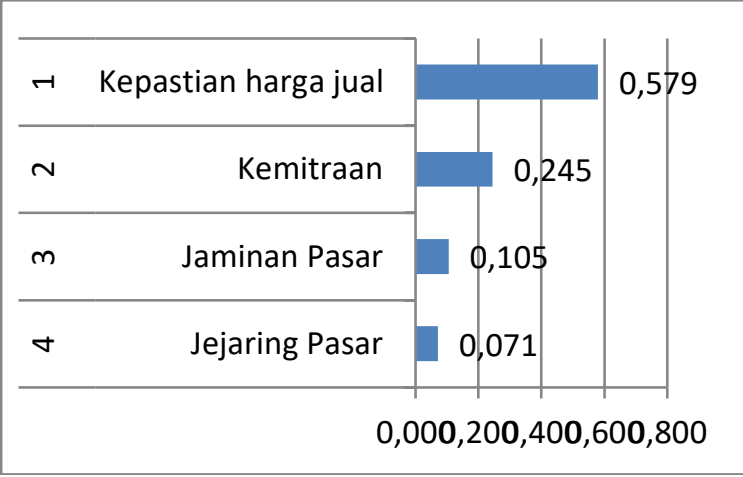

\section{Gambar 6}

\section{Urutan Prioritas sub kriteria pemasarn di Kabupaten Majalengka}

Harga benih bawang putih saat ini lebih besar dibandingkan dengan harga produk bawang putih sendiri dikarenakan masih terbatasnya benih berkualitas dan kemampuan produksi Jawa Barat khususnya Majalengka masih terbatas. Benih bawang putih yang bisa sudah dikenal dan bisa menghasilkan umbi dengan baik adalah Benih yang didatangkan dari berbagai daerah di luar Jawa barat seperti varietas sangga sembalun (Lombok), tawangmangu baru (Jawa Tengah), lumbu hijau, lumbu kuning dan lumbu putih. Harga benih bawang putih di tingkat petani untuk benih lokal berkisar 60-80 ribu per kilogram 
dengan kebutuhan per hekatan 600 kilogram benih. Sedangkan harga bawang putih di tingkat petani (basah) berkisar 10 ribu - 15 ribu per kilogram.

\section{Kriteria Penunjang}

Pada kriteri Penunjang, ada 3 sub kriteria dengan kriteria perlunya pendampingan dan penelitian terkait proses produksi bawang putih yang menjadi prioritas tertinggi di Kabupaten Majalengka

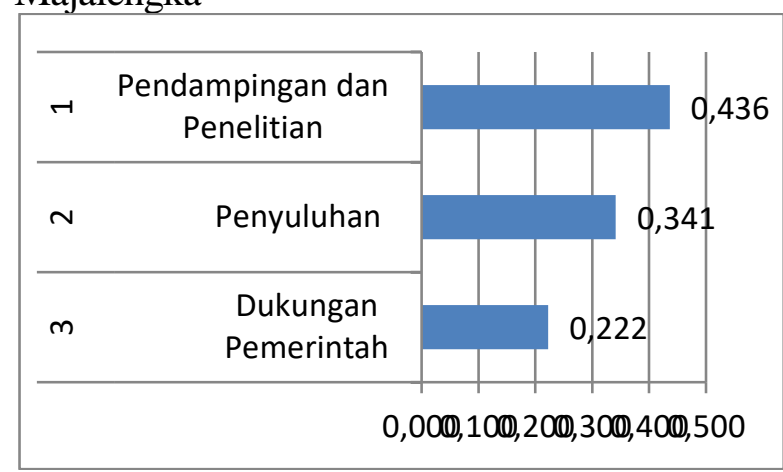

Gambar 7

\section{Urutan Prioritas sub kriteria penunjang di Kabupaten Majalengka}

Petani Kecamatan Argapura saat ini memasuki musim tanam kedua bawang putih, berdasarkan pengalaman musim tanam pertama dimana petani beranggapan teknik budidaya bawang putih sama dengan bawang merah yang sudah biasa mereka budidayakan namun hasil yang diperoleh kurang memuaskan bahkan tidak bagus untuk dijadikan sebagi benih secara komersial oleh sebab itu maka petani Kecamatan Argapura memerlukan pelatihan dan pendampingan tatacara budidaya benih bawang putih serta penangannya sampai menjadi benih yang bisa di komersialkan.

\section{Prioritas Global}

Analisa untuk menentukan secara global atau keseluruhan terhadap prioritas kriteria dan sub kriteria model proses produksi bang putih di Kabupaten Majalengka diperlihatkan pada gambar dibawah ini.

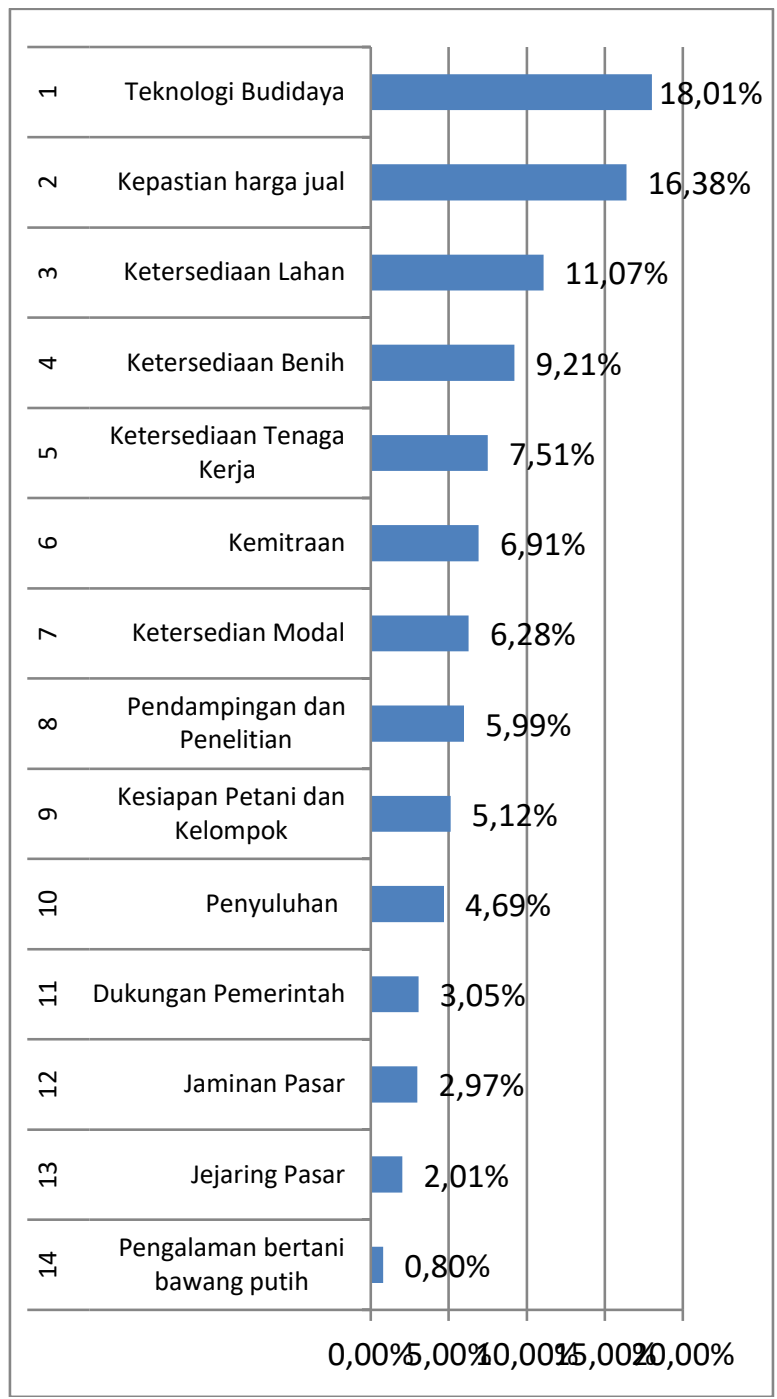

Gambar 8

\section{Urutan Prioritas global utama proses produksi bawang putih di Kabupaten Majalengka}

Dari hasil analisa prioritas global, bisa diketahui penyebab bisa dilakukannya proses produksi benih bawang putih di Kecamatan Argapura Kabupaten Majalengka yaitu: yang pertama teknologi budiaya bawang putih masih lemah sehingga pemerintah melalu dinas dan badan terkait serta petani di Jawa Barat khusus nya Kecamatan Argapura masih belum mempunyai prosedur baku untuk masing-masing jenis benih 
yang digunakan. Bahkan penggunaan benih dari importir pada tahap pertama karena adanya kewajiban importir undang-undang nomer 16 tahun 2017 tentang RPIH (Rekomendasi Impor Produk Hortikultura) dan SK Dirjen Hortikultura Nomer 221/Kpts/HK.320/D/5/2017 tentang pertunjuk pengembangan Bawang Putih oleh Pelaku usaha Produk Hortikultura dimana impotir yang bukan BUMN berkewajiban untuk menanam sebesar 5\% dari permohonan RPIH yang di setujui tidak bisa memproduksi umbi (tidak menjadi bawang putih) sehingga tidak bisa dijadikan benih untuk meningkatkan produksi bawang putih dai Jawa Barat.

Seangkan yang kedua yaitu adanya jaminan pasar untuk benih yang dihasilkan oleh pentani/kelompok tani penangkar karena meskipun proses produksi benih bisa dilakukan namun tidak mempunyai pasar maka pelaku (petani) tidak akan mau memproduksi benih lebih baik merka melakukan kegiatan yang selama ini mereka lakukan yaitu memproduksi bawang putih dari benih yang disisihkan dari hasil produksi dan digunakan langsung oleh pelaku.

\section{Alternatif Strategi Pengebangan Benih bawang Putih di Kecamatan Argapura Kabupaten Majalengka}

Sebagai salah satu kabupaten yang menyumbangkan produksi bawang putih di Jawa Barat, dari hasil analisis terhadap 3 alternatif pilihan yang harus dilakukan dengan menggunakan metode analisis hirarki proses diperlihatkan sebagai berikut:

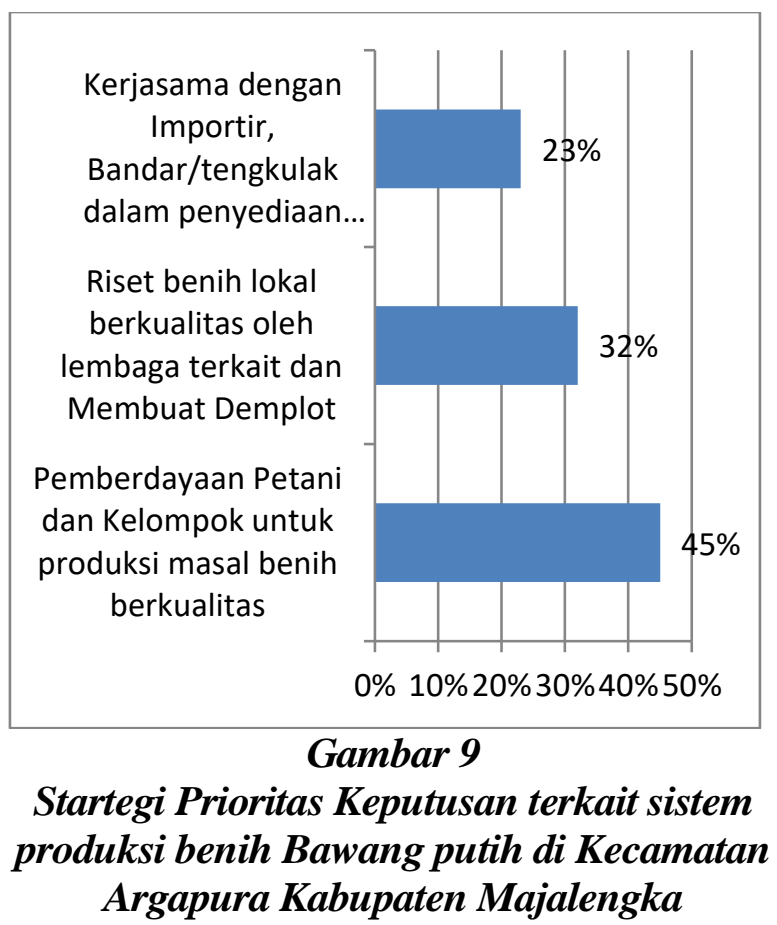

Dari tiga alternatif yang mengemuka komponen alternative yang memiliki prioritas terbesar menjadi pilihan dari para pelaku yaitu

1. Prioritas pertama adalah pemberdayaan Petani dan Kelompok untuk produksi masal benih berkulitas bisa dilakukan dengan jaminan pasar dan pendampingan dari instansi terkait.

2. Prioritas ke 2 dilakukan riset benih lokal oleh lembaga terkait dan pembuatan demplot di lokasi yan gmempunyai prospek pengembangan bawang putih untuk melakukan uji lokasi

3. Prioritas ke 3 adalah kerjasama penyediaan benih dengan importirdan/Bandar atau tengkulak, sama dengan di Kabupaten Bandung kegiatan ke 3 ini kurang memberikan dampak signifikan terhadap pengebangan produksi bawang putih di tingakt petani namun bisa dimanfaatkan untuk kerjasama pemasaran dengan jaminan harga. 
Agricore Volume 4 Nomor 1, Juli 2019

Jurnal Agribisnis dan Sosial Ekonomi Pertanian UNPAD p-ISSN No. 2528-4576 / e-ISSN No. 2615-7411

\section{Kesimpulan}

Pengembangan bawang putih di Jawa Barat sebagai bagian dari pengembangan bawang putih nasional harus didukung oleh ketersediaan dan kesiapan benih yang mampu menghasilkan bawang putih dengan baik. Selama ini pengembangan bawang putih yang dilakukan merupakan kegiatan importir bekerjasama dengan kelompok tani mitra dengan benih dari importir belum menghasilkan umbi sehingga produk yang beredar di pasar merupakan produk bawang putih dari importir.

Pengembangan benih bawang putih berkualitas yang diinisiasi oleh pemerintah bisa dilakukan dengan baik bekerjasama dengan petani atau kelompok tani dengan jaminan pembelian benih yang dihasilkan oleh petani untuk di produksi (budidayakan) oleh petani/kelompok tani guna perluasan produksi dan pengembangan sentra produksi bawang putih sehingga target swasembada bawang putih bisa menunjukkan kemajuan

\section{Terimakasih}

Terimakasih kami ucapkan kepada BPTP Jawa Barat yang telah memberikan kesempatan mengikuti kajian dan para petani penangkar benih bawang putih di berbagai kabupaten di Jawa Barat.

\section{Daftar Pustaka}

BPS. (2013). Berita Resmi Statistik No. 54/08/ Th. XVI, 1 Agustus 2017.

BPS Provinsi Jawa Barat. (2017). Jawa Barat Dalam Angka 2008-2014.

BPS Kabupaten Garut. (2017). Kabupaten
Majalengka dalam Angka 2008-2017.

Kementerian Pertanian (2017), Outlook Bawang Merah. Pusdatin Kementerian Pertanian.

T.I. Noor, P. Pardian, A. Nugraha (2016). Analisis Rantai Nilai Bawang Merah Jawa Barat, Jurnal Agricore Vol 1 No 1 ISSN: 2528-4576

RPJMN Bidang Pangan Dan Pertanian 20152019. (2013).Direktorat Pangan Dan Pertanian Kementerian Perencanaan Pembangunan Nasional/Badan Perencanaan Pembangunan Nasional.

Rizky P,Aditya. (2013). Pengaruh Produksi, Konsumsi Dan Harga Terhadap Impor Bawang Merah Di Kabupaten Brebes Tahun (2006.01 - 2010.12). Jurusan Ekonomi Pembangunan Fakultas Ekonomi Universitas Negeri Semarang.

P. Pardian 2010. Penggunaan Metode Analytic Hierarchy Process (AHP) untuk Mengetahui Tingkat Kepuasan Peserta Pelatihan Pengolahan Pepaya di Desa Padaasih Kecamatan Cibogo Kabupaten Subang.

P. Pardian, D. Esperanza, E. Wulandari (2012). Strategi Pengembangan Usaha Oncom terhadap tenaga kerja pedesaan guna penguatan ketahanan pangan dan kesejahteraan Masyarakat.

P. Pardian, T. I. Noor, A. Kusumah (2016) Analisis Penawaran dan Permintaan Bawang Merah di Provinsi Jawa Barat

Saaty, T. L. (2008a). The Analytic Network Proces. University of Pittsburgh. 
Agricore Volume 4 Nomor 1, Juli 2019

Jurnal Agribisnis dan Sosial Ekonomi Pertanian UNPAD p-ISSN No. 2528-4576 / e-ISSN No. 2615-7411

Saaty, T. L. (2008b). Decision Making with the Analytic Hierarchy Process. USA: University of Pittsburgh, PA, 15620.
Saaty, T. L. (1999). Fundamentals of The Analytic Network Process. Pittsburgh: University of Pitsburgh. 